\title{
Phenological traits of wheat response to different levels of humic acid and brassinolide
}

\author{
Shazma Anwar, Iftikhar Khan, Nawab Ali, Babar Iqbal*, Shehryar \\ Khan, Muhammad Mehran Anjum, Muhammad Owais Iqbal and \\ Saddam Hussain \\ Department of Agronomy, University of Agriculture, Peshawar - Pakistan \\ *Corresponding author's email: agronomist19388@yahoo.com \\ Citation \\ Shazma Anwar, Iftikhar Khan, Nawab Ali, Babar Iqbal, Shehryar Khan, Muhammad Mehran Anjum, \\ Muhammad Owais Iqbal and Saddam Hussain. Phenological traits of wheat response to different levels of \\ humic acid and brassinolide. Pure and Applied Biology. Vol. 5, Issue 4, pp782-787.
}

http://dx.doi.org/10.19045/bspab.2016.50098

\begin{tabular}{|c|c|c|c|}
\hline Received: 04/01/2016 & Revised: 25/07/2016 & Accepted: 04/08/2016 & Online First: 08/08/2016 \\
\hline
\end{tabular}

\section{Abstract}

A field experiment was conducted to investigate phonological traits of wheat response to different levels of humic acid and brassinolide at New Developmental Farm The University of Agriculture, Peshawar during Rabi season 2009 -10. The wheat variety Saleem 2000 was sown. The design used was Randomized Complete Block Design (RCBD) with four replications in split plot arrangement. Humic acid was assigned to main plot whereas brassinolide was allotted to sub plot. Plot size of $3 \mathrm{x}$ $3.5 \mathrm{~m}$ having 10 rows, $30 \mathrm{~cm}$ apart were used. Four levels of humic acid $\left(0,1,2\right.$ and $\left.4 \mathrm{~kg} \mathrm{ha}^{-1}\right)$ were applied at sowing times. Whereas 5 levels of brassinolide $\left(0,0.5,1,1.5\right.$ and $\left.2 \mathrm{mg} \mathrm{L}^{-1}\right)$ were sprayed in foliar form at the tillering stage. Application of $4 \mathrm{~kg} \mathrm{HA} \mathrm{ha}^{-1}$ delayed days to heading (117.44). Increasing humic acid levels up to $2 \mathrm{~kg} \mathrm{ha}^{-1}$ delayed anthesis (124.18) days and maturity (156) days and produced taller (82.69) plants. Increasing brassinolide concentrations up to $2 \mathrm{mg} \mathrm{L}^{-1}$ delayed days to heading (118.25days), anthesis (124.63days) and maturity (158days). Taller $(89.56 \mathrm{~cm})$ plants were produced through the application of $2 \mathrm{mg} \mathrm{BL}^{-1}$. Increasing brassinolide concentration up to $2 \mathrm{mg} \mathrm{L}^{-1}$ as combined with $2 \mathrm{~kg} \mathrm{HA} \mathrm{ha}^{-1}$ delayed days to anthesis. Application of $2 \mathrm{~kg} \mathrm{HA} \mathrm{ha}^{-1}$ enhanced wheat phenology and thus is recommended for wheat cultivation in the agro climatic conditions of Peshawar for improved phonological traits. Application of $2 \mathrm{mg} \mathrm{BL}^{-1}$ improved wheat phenology and thus is recommended for wheat cultivation in the agro climatic conditions of Peshawar for better phonological traits.

Keywords: Wheat (Triticum aestivum L.); Humic acid; Brassinolide; Phenological; Traits

\section{Introduction}

Wheat plays a key role in human economic and social development in addition to food. It ranks first among the cereals on production basis. Production of wheat in Pakistan has increased manifold over the past few decades, yet we are faced with food shortage. There are two ways to increase the yield, by bringing more area under cultivation or to increase yield per unit area. As the land is fixed, so it is important to use the available land more efficiently. An area of 9096(000) ha was cultivated for wheat which produced an every yield $2657 \mathrm{~kg} \mathrm{ha}^{-1}$ [1].

Humic acid and brassinolide are important compounds that help to increase agricultural production. Humic acid has positive effects on enzyme activity, plant nutrients, growth stimulant and can be considered as "plant food". Humic acid is most responsive in high carbonate crops 
like potato, carrot, maize, rice, wheat [2]. Many other studies have demonstrated the practical importance of humic acid application in crop yield of wheat, maize, cotton, sugar beet and groundnut and improvement in soil physio-chemical conditions [3-6]. In many studies, humic and fulvic acids preparations were reported to increase the uptake of mineral elements to promote the root length [7] and to increase the fresh and dry weights of crop plants [8].

Humic acid (HA) is produced naturally by extracting from our lignitic coal [9]. Humic acid gives organic corban 51-57\%, $\mathrm{N}(4-6 \%), \mathrm{P}(0.2-1 \%)$ and has the capability to enhance crops yields through provision of nitrogen and phosphorus to the plants. But the quantity of humic acid applied in the form of fertilizer is upto $2 \mathrm{~kg} \mathrm{ha}^{-1}$ which can provide 0.04 to $0.08 \mathrm{~kg}$ nitrogen ha ${ }^{-1}$ and $0.004 \mathrm{~kg}$ phosphorus $\mathrm{ha}^{-1}$ to the soil which is very less as compared to the nutritional need of crops [10].

Brassinolide is a steroid compound that play role in cell division and growth discovered in 1973 [11]. Brassinolide provide protection to plants during chilling and drought stress. Brassinolide has been reported to work with auxin to promote cell expansion and elongation. Brassinolide also increases uptake of plant nutrients [12]. Appliance of brassinolide to crops helps to beat environmental stress such as cold, salt tolerance, and herbicidal injury. Brassinolide have been evaluated for use in improving crop yield, quality, stress tolerance, and disease resistance and promising results have been reported with several plants [13]

Brassinolide also increases uptake of plant nutrients. Various carbohydrate fractions of many plants increases due to Brassinosteroids application [14]. Genetic manipulation of brassinolide activity has indeed led to increase in crop yield of 20$60 \%$ confirming the value of further research to increase productivity [15]. Homobrassinolide stimulates wheat yield which is manifested by an increase in the no of grains spike ${ }^{-1,}$ spikes $\mathrm{m}^{-2}$ and thousand grains weight [16]. Brassinolide application improves the leaf water economy and $\mathrm{CO}_{2}$ assimilation and enable plant to withstand drought. Root application of homobrassinolide results in enhanced total grain yield and thousand grain weight of both salt stressed cultivars [17]. 28 homobrassinolide significantly increased the yield of wheat upto $6.7 \mathrm{t} \mathrm{ha}^{-1}$ as compared to the controlled field which produced $5.7 \mathrm{t} \mathrm{ha}^{-1}$ [18]. Homobrassinolide increases photosynthesis physiologically and thus increases chlorophyll content [14] Keeping in view the role of humic acid and brassinolide, the present study was carried out to investigate the phonological traits of wheat.

\section{Materials and methods}

In order to study "phonological traits of wheat response to different levels of humic acid and brassinolide" a field experiment was conducted during Rabi season 20092010 at New Developmental Farm, The University of Agriculture Peshawar. The different levels of humic acid and brassinolide were planned as Main plot included Humic acid levels $\mathrm{HA}_{0}\left(0 \mathrm{~kg} \mathrm{ha}^{-}\right.$ $\left.{ }^{1}\right), \mathrm{HA}_{1}\left(1 \mathrm{~kg} \mathrm{ha}^{-1}\right), \mathrm{HA}_{2}\left(2 \mathrm{~kg} \mathrm{ha}^{-1}\right), \mathrm{HA}_{3}$ (4 $\mathrm{kg} \mathrm{ha} \mathrm{ha}^{-1}$ ) while subplot included Brassinolide Concentrations levels B0 (0 $\left.\mathrm{mg} \mathrm{L} \mathrm{L}^{-1}\right), \mathrm{B}_{1}\left(0.5 \mathrm{mg} \mathrm{L}^{-1}\right), \mathrm{B}_{2}\left(1.0 \mathrm{mg} \mathrm{L}^{-1}\right)$, $\mathrm{B}_{3}\left(1.5 \mathrm{mg} \mathrm{L} \mathrm{L}^{-1}\right), \mathrm{B}_{4}\left(2.0 \mathrm{mg} \mathrm{L}^{-1}\right)$. The study was carried out in randomized complete block design with split plot arrangement having four replications. Humic acid was assigned to main plot while brassinolide was allotted to sub plot. Wheat variety Saleem 2000 was sown at a seed rate of $100 \mathrm{~kg} \mathrm{ha}^{-1}$. Nitrogen and Phosphorus was applied at the rate $120 \mathrm{~kg}$ $\mathrm{ha}^{-1}$ and $60 \mathrm{~kg} \mathrm{ha}^{-1}$ respectively. Half of nitrogen and all phosphorus were applied at the time of seed bed preparation while the remaining was applied with first irrigation. A plot size of $3 \mathrm{~m} \times 3.5 \mathrm{~m}$ was maintained with row to row distance of 30 $\mathrm{cm}$ having ten rows. Humic acid was applied at time of sowing while brassinolide was applied at start of tillering 
stage as a foliar spray. Before sowing the field was prepare and was ploughed with normal cultivator. All agronomic practices were carried out uniformly. Data was subscribed on the parameters days to emergence, emergence $\mathrm{m}^{-2}$, days to heading, days to anthesis, plant height, days to maturity. Days to emergence in each sub plot was recorded by counting number of days from sowing to the date on which $80 \%$ seedling emerged. In each sub plot seedlings at three randomly selected rows of spots in one meter length row were counted in each plot and averaged. Days to heading were recorded by counting number of days from sowing to the date on which $80 \%$ plants developed spikes in each sub plot. In each sub plot days to anthesis were recorded by counting days from sowing till $80 \%$ spikes reached anthesis stage. Data on plant height was recorded by measuring the height from lower node (crown) to tip of spike of ten randomly selected tillers in each sub plot. Data regarding days to physiological maturity was noted from the date of sowing to the data when all plants physiological mature in each sub plots. Data were analyzed according to
Randomized Complete Block Design (RCBD) with split plot arrangement. LSD test was also carried out to test the significant differences among the means of different treatments [19].

\section{Results and discussion}

\section{Days to emergence and emergence $\mathbf{m}^{-2}$}

Data regarding days to emergence of wheat as affected by humic acid levels is presented in Table. 1. The analysis of the data shows that humic acid application had no significant effect on days to emergence of wheat. Data regarding emergence $\mathrm{m}^{-2}$ of wheat as affected by humic acid level is also presented in Table.1. The analysis of the data shows that emergence $\mathrm{m}^{-2}$ was also not significantly affected by humic acid levels. Data regarding days to emergence of wheat as affected by humic acid levels shows that humic acid application had no significant effect on days to emergence of wheat. Similarly, emergence $\mathrm{m}^{-2}$ of wheat as affected by humic acid level also shows that emergence $\mathrm{m}^{-2}$ was also not significantly affected by humic acid levels. This may be due to the reason that basically emergence depends on internal moisture and nutrients for germination.

\section{Table 1. Days to emergence and emergences $\mathrm{m}^{-2}$ of wheat as affected by humic acid}

\section{Levels}

\begin{tabular}{|l|c|c|}
\hline Humic acid levels $\left(\mathbf{k g ~ h a}^{-\mathbf{1}}\right)$ & Days to emergence & Emergence $\mathbf{~ m}^{-\mathbf{2}}$ \\
\hline 0 & 10.5 & 117 \\
\hline 1 & 11.5 & 113 \\
\hline 2 & 10.5 & 113 \\
\hline 4 & 11.5 & 115 \\
\hline LSD $_{(\mathbf{0 . 0 5})}$ & Ns & Ns \\
\hline
\end{tabular}

\section{Days to heading}

Data concerning days to heading of wheat as affected by humic acid and brassinolide levels is presented in Table. 2. Humic acid and brassinolide significantly affected days to heading of wheat. However, the interactive effect of humic acid and brassinolide was non significant. The sub plot where $4 \mathrm{~kg} \mathrm{HA} \mathrm{ha}^{-1}$ was applied took maximum (117.44) days for heading as compared to the rest. In case of brassinolide maximum days to heading
(118.25) were recorded from the sub plot where $1.5 \mathrm{mg} \mathrm{BL}^{-1}$ was applied as compared to the rest. Humic acid and brassinolide significantly affected days to heading of wheat. However, the interactive effect of humic acid and brassinolide was non significant. Maximum days to heading were recorded in plots treated with $4 \mathrm{~kg}$ $\mathrm{HA} \mathrm{ha}{ }^{-1}$ as compared to the rest. In case of brassinolide maximum days to heading were recorded from the sub plot where 1.5 $\mathrm{mg} \mathrm{BL}^{-1}$ was applied as compared to the 
rest.

\section{Days to anthesis}

Data regarding days to anthesis of wheat as affected by humic acid and brassinolide is presented in Table 2. Analysis of data revealed that humic acid and brassinolide had significant effect on days to anthesis. Similarly, the interactive effect of humic acid and brassinolide was also significant. Increasing levels of humic acid application had delayed days to anthesis. The maximum days to anthesis (124.18 days) were recorded in sub plots having $2 \mathrm{~kg} \mathrm{HA}$ $\mathrm{ha}^{-1}$ as compared to minimum days to anthesis (119.05 days) from $0 \mathrm{~kg} \mathrm{HA} \mathrm{ha}{ }^{-1}$. In case of brassinolide the highest days to anthesis (124.63) were taken by sub plots treated with $2 \mathrm{mg} \mathrm{BL}^{-1}$ while minimum days to anthesis (117.43) were taken by sub plots at $0 \mathrm{mg} \mathrm{BL}^{-1}$. Regarding the interactive effect of humic acid and brassinolide, with increasing brassinolide concentration days to anthesis were increased with increasing humic acid levels till $2 \mathrm{~kg} \mathrm{HA} \mathrm{ha}^{-1}$ and then decreased with $4 \mathrm{~kg} \mathrm{HA} \mathrm{ha}{ }^{-1}$. Humic acid and brassinolide had significant effect on days to anthesis. Increasing levels of humic acid application had delayed days to anthesis. The maximum days to anthesis were recorded in sub plots having $2 \mathrm{~kg} \mathrm{HA} \mathrm{ha}{ }^{-1}$ as compared to minimum days to anthesis from $0 \mathrm{~kg} \mathrm{HA} \mathrm{ha}{ }^{-1}$ treared plots. Humic acid application increased the spike fertility and took more days than the control [20]. In case of brassinolide the highest days to anthesis were taken by sub plots treated with $2 \mathrm{mg} \mathrm{BL}{ }^{-1}$ while minimum days to anthesis were taken by sub plots at $0 \mathrm{mg} \mathrm{BL}^{-1}$. Brassiholide regulate plant metabolic processes by interacting with other plant hormones [21] which could be the possible reason.

\section{Plant height}

Data pertaining to plant height of wheat as affected by humic acid and brassinolide is shown in Table 2. Statistical analysis of the data revealed that plant height was significant affected by humic acid and brssinolide whereas the interactive affect of humic acid and brassinolide was not significant. Taller (82.69) plants were maintained by sub plots that received $2 \mathrm{~kg}$ HA $\mathrm{ha}^{-1}$ as compared to controlled plots which produce smaller (74.60) plants. Regarding brassinolide application higher plant height (89.56) was recorded from 2 mg BL-1 treated plants as compared to lower (71.63) with application of $0 \mathrm{mg} \mathrm{BL}^{-}$ 1. Plant height was significantly affected by humic acid and brssinolide. Taller plants were maintained by sub plots that received $2 \mathrm{~kg} \mathrm{HA} \mathrm{ha}{ }^{-1}$ as compared to controlled plots which produced smaller plants. It may be due to the reason that humic acid increases nutrients availability that in turn increases plant height [22]. Regarding brassinolide application higher plant height was recorded from $2 \mathrm{mg} \mathrm{BL}^{-1}$ treated plants as compared to lower with application of $0 \mathrm{mg} \mathrm{BL}{ }^{-1}$. The possible explanation for this may be that brassinolide are involved in processes which are more related to plant growth including photomorphogenesis and cell expansion in the presence of a potentially growth limiting cell wall [23].

\section{Days to physiological maturity}

Data regarding days to physiological maturity of wheat as affected by humic acid and brassinolide is presented in Table 2. Analysis of the data indicated that humic acid and brassinolide had significantly affected physiological maturity of wheat. While the interactive effect of humic acid and brassinolide was not significant. Delayed physiological maturity (156 days) was observed with application of $2 \mathrm{~kg} \mathrm{HA} \mathrm{ha}{ }^{-1}$ which is statistically at par with 1 and $4 \mathrm{~kg} \mathrm{HA} \mathrm{ha}^{-1}$. Early physiological maturity (152 days) in control plots was noticed. Regarding brassinolide $2 \mathrm{mg} \mathrm{BL}^{-1}$ increased physiological maturity up to (156 days). While minimum days (149) were observed with no application of brassinolide. Humic acid and brassinolide had significantly affected physiological maturity of wheat. Delayed physiological maturity was observed with application of $2 \mathrm{~kg} \mathrm{HA} \mathrm{ha}^{-1}$ 
which is statistically at par with 1 and $4 \mathrm{~kg}$ $\mathrm{HA} \mathrm{ha}{ }^{-1}$. Early physiological maturity in control plots was noticed. Humic acid increased spike fertility which resulted in increased no of days to get matured [20]. Regarding brassinolide $2 \mathrm{mg} \mathrm{BL}^{-1}$ increased physiological maturity. While minimum days to maturity were observed with no application of brassinolide. Brassinolide is a steroid compound that play role in cell division and growth discovered in 1973 [11]. Brassinolide has been reported to work with auxin to promote cell expansion and elongation. Brassinolide also increases uptake of plant nutrients [12].

Table 2. Days to heading, days to anthesis, plant height and days to maturity of wheat as affected by humic acid and brassinolide

\begin{tabular}{lllll}
\hline & & & \\
\hline
\end{tabular}

\section{Conclusion and recommendation}

It was concluded from the results of this experiment that humic acid level at the rate of $2 \mathrm{~kg} \mathrm{ha}^{-1}$ enhanced phonological traits. Considering brassinolide effect, the application of brassionlide at the rate of 2 $\mathrm{mg} \mathrm{\textrm {L } ^ { - 1 }}$ performed better as compared to rest. Based on results and conclusion, it is recommended that Humic acid at the rate of $2 \mathrm{~kg} \mathrm{ha}^{-1}$ and brassinolide at $2 \mathrm{mg} \mathrm{L}^{-1}$ can be used for better phenology of wheat in Peshawar valley.

\section{Authors' contributions}

Conceived and designed the experiments: $S$ Anwar \& I Khan, Performed the experiments: I Khan, B Iqbal \& S Khan, Analyzed the data: S Anwar \& I Khan, Contributed reagents/ materials/ analysis tools: N Ali, MM Anjum, MO Iqbal \& S Hussain, Wrote the paper: S Anwar \& B Iqbal.

\section{References}

1. MINFA. (2009). Ministry for food and Agriculture. Agricultural statistics of Pakistan 2008-09. Govt of Pakistan, Islamabad. 
2. Lee YS \& Bartlett RJ (1976). Stimulation of plant growth by humic substances. Soil Sci Soc Am J. 40: 876-879.

3. Petrovic P, Vitrovic D \& Jablanoic M (1982). Investigations of biological effects of humic acids. Acta Bio Med Exper Budapest. 7: 21-25.

4. Nisar A \& Mir S (1989). Lignitic coal utilization in the form of HA as fertilizer and soil conditioner. Sci Tech Develop. 8: 23-26.

5. Senn TL 1(991) Humic acid is one of the major component of humates. Humates in Agric. Acres USA: 15-21.

6. Piccolic A, Nardi S \& Concheri G (1992). Structure of humic substances as

Regulator to nitrate uptake and growth regulation on plant system. Soil Boil Biochem.24:373-380

7. Vaughan D \& Linehan DJ (1976). The growth of wheat plants in humic acid solutions under axenic conditions. Plant and Soil. 44(2), 445-449.

8. Chen Y, Nobili DE \& Avaid T (2004). Stimulatory effect of humic substances on Plant growth. Soil organic matter and sustainable agriculture. Weil R.R., eds CRC Press, NY, USA, 103-129.

9. Hay SM \& Mer S (1998). The lignite coal desired humic acid and the prospective utilization in Pakistan Agricultures industry. Sci Tech and Dev 17 (3): 32-40.

10. Sharif M, Khattak RA \& Sarir MS (2002). Wheat yield and nutrients accumulation in response to humic acid and chemical fertilizer. Sarhad J Agric 18(3): 323-329.

11. Clouse SD \& Sasse JM (1998). Brassinosteroids: Essential regulators of plantgrowth and development. Annu Rev. Plant Phyisol. Plant Mol Biol 49: 427-51.

12. Nemhauser AB (2004). Interdependenccy of Brassinosteroid and Auxin signaling in Arabiodopsis. $J$ Agric Food chein. 55(16):8207-8215

13. Cutler HG, Yokota T \& Adam G (1991). Brassinosteroids Chemistry, Bioactivity and Applications, ACS Symp. Ser. 474, American Chemical Society, Washington, D.C.
14. Talaat IM \& Youssef AA (1998). Response of Roselle plants (Hibiscus sabdariffa L.) to some growth regulating substances. Egypt J Phys Sci. 22(3): 327338.

15. Divi UK \& Krishna P (2009). Brassinosteroid: a biotechnological target for enhancing crop yield and stress tolerance. N Biotechnol. 26: 131-136.

16. Sairam RK (1994). Effect of homobrassinolide application on metabolic activity and grain yield of wheat under normal and water-stress condition. J of Agron and Crop Sci. 173: 11-16.

17. Ali Q, Athar H \& Ashraf M (2008). Modulation of growth, photosynthetic capacity and water relations in salt stressed wheat plants by exogenously applied 24 epibrassinolide. Plant Growth Regul. 56: 107-116.

18. Ramraj VM, Vyas BN, Godrej NB, Mistry KB, Swami BN \& Singh N (1997). Effects of 28-homobrassinolide on yields of wheat, rice, groundnut, mustard, potato and cotton. J Agric Sci. 128: 405-413.

19. Steel RGD \& Torrie JH (1980). Principles and procedure of statistics. A biological approach $2^{\text {nd }}$ ed. McGraw Hill Inc. New York.

20. Delfine SR, Togretti, Desidira E \& Alvano A (2005). Effect of folair application of nitrogen and humic acid on gorwth and yield of duram wheat. Agron Sustaible development. 25:183-191.

21. Yun HR, Joo S, Park CH, Kim S, Chang SC \& Kim SY (2009). Effects of brassinolide and IAA on ethylene production and elongation in maize primary roots. J Plant Biol. 52: 268-274.

22. Iqtidar $\mathrm{H}$, Ayyaz $\mathrm{KM} \&$ Ahmad KE (2006). Bread wheat varieties as influenced by different nitrogen levels. $J$ Zhejiang Univ Sci. 7: 70-78

23. Zurek DM, Rayle DL, McMorris TC \& Clouse SD (1994). Investigation of gene expression, growth kinetics, and wall extensibility during brassinosteroidregulated stem elongation. Plant Physiol. 104: 505-513. 